\title{
Potentiometric Aptasensing of Listeria monocytogenes Using Protamine as an Indicator
}

\author{
Jiawang Ding, ${ }^{\dagger, \dagger}$ Jiahong Lei, ${ }^{\dagger, \dagger}$ Xia Ma, ${ }^{\dagger}$ Jun Gong, ${ }^{\dagger}$ and Wei Qin ${ }^{*}{ }^{\dagger}$
}

${ }^{\dagger}$ Key Laboratory of Coastal Environmental Processes and Ecological Remediation, Yantai Institute of Coastal Zone Research (YIC), Chinese Academy of Sciences (CAS); Shandong Provincial Key Laboratory of Coastal Environmental Processes, YICCAS, Yantai, Shandong 264003, P. R. China

${ }^{\ddagger}$ University of Chinese Academy of Sciences, Beijing 100049, P. R. China

\section{Supporting Information}

\begin{abstract}
Exposure to pathogens in recreational or drinking water is a serious public health concern. It is important to rapidly determine and identify trace levels of pathogens in real environmental samples. We report here on a label-free potentiometric aptasensor for rapid, sensitive, and selective detection of Listeria monocytogenes (LM), a pathogen widely distributed in the environment. An aptamer binds specifically to internalin A, a surface protein present in LM cells. The target-binding event prevents the aptamer from

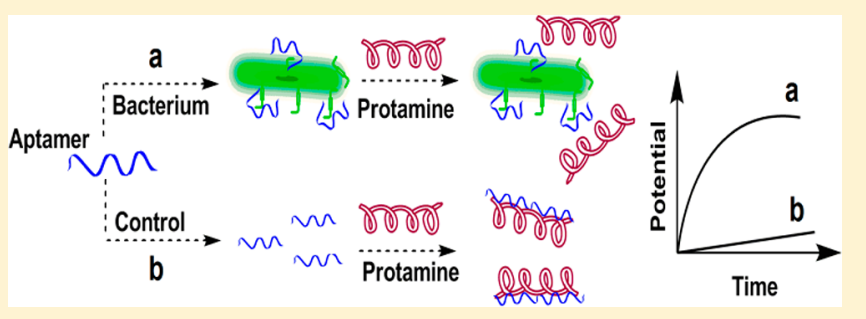
electrostatically interacting with protamine, which can be sensitively detected using a polycation-sensitive membrane electrode. Using this method, $\mathrm{LM}$ can be detected down to $10 \mathrm{CFU} \mathrm{mL}^{-1}$. Coupled to an online filtration system, the bioassay has been evaluated with spiked coastal seawater samples and shows good recovery and high accuracy. This work demonstrates the possibility of developing potentiometric aptasensors for determination and identification of various bacteria in environmental samples.
\end{abstract}

Listeria monocytogenes (LM), a Gram-positive bacterium responsible for listeriosis, is one of the most virulent foodborne pathogens with $20-30 \%$ of clinical infections resulting in death. ${ }^{1-3}$ Because of the widespread nature of the organism, it is widely distributed in the environmental mediums such as waters, sediments, and seafoods. Additionally, LM can tolerate high concentrations of salt, temperatures between 3 and $45^{\circ} \mathrm{C}$, and $\mathrm{pHs}$ between 5.4 and 9.6. ${ }^{4,5}$ The presence of $\mathrm{LM}$ in an aquatic environment polluted with urban runoffs and effluents from publicly owned treatment works poses a threat to human health. ${ }^{6,7}$ Therefore, there is a broad consensus on the need of sensitive monitoring LM in the aquatic environment in order to protect human health.

Conventional methods as well as recently developed techniques such as cell culture, microscopy, biochemical tests, luminescence, ELISA (enzyme-linked immunosorbent assays), and PCR (polymerase chain reactions) ${ }^{8-11}$ could provide accurate validation but have the drawbacks of intensive labor, time-consuming procedures, and/or poor sensitivity. Recently, the development and applications of biosensors for rapid and sensitive detection of bacterial cells have attracted considerable attention. Immunosensors with different readout mechanisms are among the most promising. Those immunosensors typically have detection limits of $10^{3}-10^{6} \mathrm{CFU} \mathrm{mL} \mathrm{m}^{-1}$ and analysis times of $0.2-2 \mathrm{~h},{ }^{8,9}$ which may limit their wide applications. As an alternative to traditional antibody-based immunoassays, antimicrobial peptides (AMPs) have been used as molecular recognition elements in the electronic biosensing platform for pathogenic bacteria. ${ }^{12}$ However, the selectivity of this method needs to be improved because of the semiselective binding of AMPs to target cells. Thus, new receptors are still highly desired to meet the demands for sensitive and selective detection of bacteria.

Aptamers are single-stranded DNA or RNA oligonucleotides selected in vitro to bind a variety of analytes ranging from small ions to whole cells with high specificities and affinities. ${ }^{13}$ The simplicity and robustness of aptamers make them an ideal biorecognition element for sensing targets in environmental samples. ${ }^{14,15}$ To this end, a number of aptasensors based on optical, electrochemical, and mass-sensitive transduction have been reported for pathogenic microorganism typing and detection. ${ }^{16-18}$ Among these methods, electrochemical aptasensors are widely used for identification and quantification of foodborne pathogens. ${ }^{19-21}$ However, these methods always require probe labeling and aptamer immobilization, which may affect the binding affinities between bacteria and their aptamers. Moreover, some immobilized aptamers cannot efficiently capture the bacterial cells, which limits their applications via the heterogeneous biosensing mode. Thus, it is of great importance to realize label-free electrochemical aptasensing of pathogen bacteria in a homogeneous solution.

Received: June 26, 2014

Accepted: September 14, 2014

Published: September 14, 2014 
Recently, we developed a label-free potentiometric aptasensing concept to monitor small analytes (e.g., adenosine triphosphate) in a homogeneous solution where target binding-induced conformational changes are involved. ${ }^{22}$ Herein, the aptasensing of whole cells is described and a label-free potentiometric aptasensor for detection of LM is presented. An aptamer specific for internalin A ( InlA), which is a surface protein existing in all LM strains and serves as a molecular marker for pathogenesis, has been selected as a recognition element for the detection of $\mathrm{LM}^{23}$ Protamine, a group of arginine-rich polycationic proteins extracted from the Salmonidae fish family, is used as an indicator for the transduction of potential signal. ${ }^{24}$ It will be shown that LM can be sensitively and selectively detected via homogeneous analysis. An online filtration system coupled to the potentiometric aptasensing effectively eliminates the sample matrixes and thus allows for the determination of LM in coastal seawater.

\section{EXPERIMENTAL SECTION}

Materials and Methods. 2-Nitrophenyl octyl ether (oNPOE), tetradodecylammonium tetrakis(4-chlorophenyl)borate (ETH 500), high molecular weight poly(vinyl chloride) (PVC), dinonylnaphthalene sulfonic acid (DNNS, 50 wt \% solution in heptane), protamine sulfate salt from herring, and tris(hydroxymethyl)-aminomethane (Tris) were purchased from Sigma. Bacterial strains for Escherichia coli O157:H7, Salmonella typhimurium, Listeria iuanuii, and Listeria monocytogenes (LM) were kindly provided by Yantai Import and Export Inspection and Quarantine Bureau. The number of colony-forming units per $\mathrm{mL}\left(\mathrm{CFU} \mathrm{mL}{ }^{-1}\right)$ for each culture was determined by the surface plate counting method. The aptamer for LM was synthesized by Shanghai Sangon Biotechnology Co. Ltd. (Shanghai, China), and the sequence was 5'-ATC CAT GGG GCG GAGATG AGG GGG AGG AGG GCG GGT ACC CGG TTGAT-3'. For control experiments, the DNA with a sequence of $5^{\prime}$-TAG GTA CCC CGC CTC TAC TCC CCC TCC TCC CGC CCA TGG GCC AAC TA-3' was used.

The morphologies of LM were characterized by scanning electron microscopy (SEM, JSM5600 LV, operating at $5.0 \mathrm{kV}$ ). Usually, LM does not retain its shape when it is dry. The LM cells were fixed on a template with $2.5 \%$ glutaraldehyde in phosphate buffer $(0.1 \mathrm{M})$ and dehydrated in graded alcohols. The zeta potentials of the pathogenic bacteria were measured on a Malvern Zeta sizer Nano-ZS90 (ZEN3590, Malvern, UK). The bacterial solutions were prepared with $3.0 \mathrm{~mL}$ of Trisbuffered saline (TBS buffer, Tris base $10 \mathrm{mM}, \mathrm{NaCl} 0.85 \%$, $\mathrm{pH}$ 8.0).

Electrode Preparation. The polymeric polycation-sensitive membranes contained 1.0 wt \% DNNS, 1.0 wt \% ETH 500, 49.0 wt \% $o$-NPOE, and 49.0 wt \% PVC. The membrane electrodes were prepared as described before. ${ }^{25}$ The rotating electrode configuration was used for both titration and direct potential measurements (see the Supporting Information). ${ }^{26,27}$ The rotation speed was $3000 \mathrm{rpm}$.

Determination of LM via Direct Potential Measurement. All the measurements were carried out at $25 \pm 2{ }^{\circ} \mathrm{C}$ using a Model PXSJ-216 digital ion analyzer (Shanghai Leici Instruments Factory, China). Measurements of electromotive force (EMF) were performed in the galvanic cell: $\mathrm{Ag} / \mathrm{AgCl} / 3$ $\mathrm{M} \mathrm{KCl} /$ /sample solution/polymeric membrane/inner filling solution/ $\mathrm{AgCl} / \mathrm{Ag}$. $50 \mathrm{mM}$, pH 7.4 Tris- $\mathrm{HCl}$ buffer solution containing $0.12 \mathrm{M} \mathrm{NaCl}$ was used as the inner filling solution.
The LM aptamer $(0.33 \mu \mathrm{M})$ was mixed with the bacterium at various concentrations in $3.0 \mathrm{~mL}$ of TBS buffer. After incubation at room temperature for $30 \mathrm{~min}, 10 \mu \mathrm{g} \mathrm{mL}-1$ protamine was added. The potential responses were recorded with the polycation sensitive membrane rotating electrode. The potential difference measured at $10 \mathrm{~min}$ between the baseline and the potential response in the presence of LM was used for quantification.

Seawater Analysis. The Yantai coastal seawater samples (Yellow Sea, China) were collected. A poly(ether sulfone) membrane (diameter: $25 \mathrm{~mm}$; pore size: $0.2 \mu \mathrm{m}$; Pall Corporation, Ann Arbor, MI, USA) was used for sample filtration. Consecutive filtering of $20 \mathrm{~mL}$ of seawater and washing with TBS $(5.0 \mathrm{~mL})$ were done with an online filtration system to enrich the bacterium and also eliminate the charged species that are usually present in real samples (Figure S1, Supporting Information). ${ }^{20}$ Each analyzed sample was simultaneously evaluated following the standard plate count method in triplicate using the Listera chromogenic medium to validate the proposed method.

\section{RESULTS AND DISCUSSION}

The LM cells have a negative charge according to the zeta potential measurement $(-14.2 \mathrm{mV})$, which is attributed to the cell wall constituents such as phosphate and carboxylate groups. ${ }^{28}$ Therefore, protamine with a positive surface charge can bind to the anionic bacteria through electrostatic interactions. Bacteria might be sensed by a protamine-sensitive membrane electrode. However, the poor selectivity and the low sensitivity of this method could restrict its applications. Alternatively, the present potentiometric sensor design features two main components: (1) an aptamer, a 47 mer singlestranded DNA, to provide target recognition with the binding affinity and selectivity comparable with those of antibodies; (2) protamine, a group of arginine-rich polycationic proteins, to provide a potential readout with high sensitivity and reproducibility.

The whole sensing procedure is illustrated in Figure 1A. In the absence of the target bacterial cells (a), the aptamer with negatively charged phosphate groups interacts electrostatically

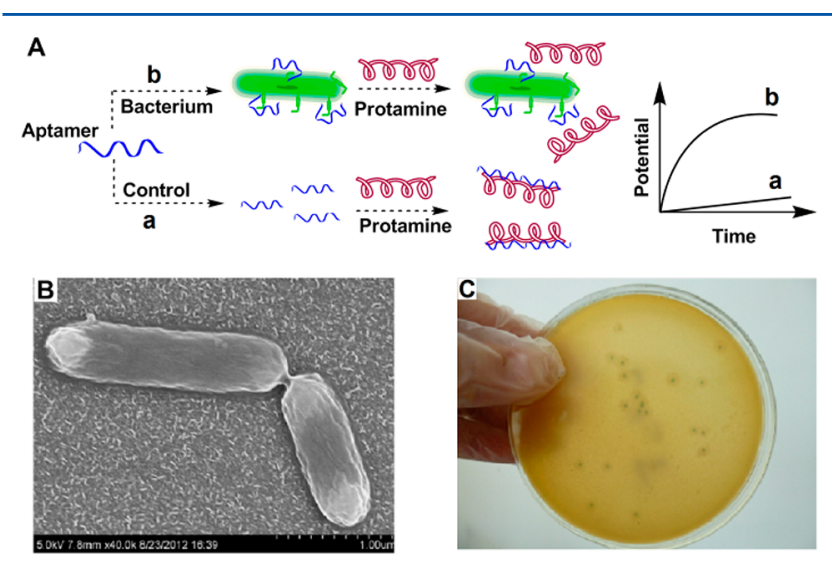

Figure 1. (A) Schematic illustration of potentiometric aptasensing of bacterial cells using a polycation-sensitive membrane electrode. (B) SEM image of Listeria monocytogenes cells. (C) Listeria monocytogenes in chromogenic medium. The medium can differentiate the colonies of Listeria monocytogenes from other organisms and the rest of Listeria spp. The Listeria monocytogenes areas are blue in color with opaque white haloes surrounding them. 
with the positively charged guanidinium groups of protamine to form a biocomplex, thus inhibiting the potential response of protamine. In the presence of the target bacterium, the aptamer binds specifically to the bacteria via reaction incubation (b). Such target binding effectively prevents the aptamer from electrostatically interacting with protamine, which allows protamine to be detected by the polycation-sensitive membrane electrode. Herein, Listeria monocytogenes, a pathogen widely distributed in the environment was selected as a model. It was characterized by scanning electron microscopy (Figure 1B) and identified by the Listeria chromogenic medium (Figure 1C).

Potentiometric titrations were performed to prove the sensing principle. Protamine was chosen as a signal reporter because of its stability to a wide range of temperature, $\mathrm{pH}$, and ionic strength conditions. Moreover, the concentration of protamine can be monitored using the polymeric membrane doped with DNNS that yield large and reproducible potentiometric responses toward protamine. ${ }^{29}$ As shown in Figure $2 \mathrm{~A}$, the aptamer electrostatically binds to protamine and
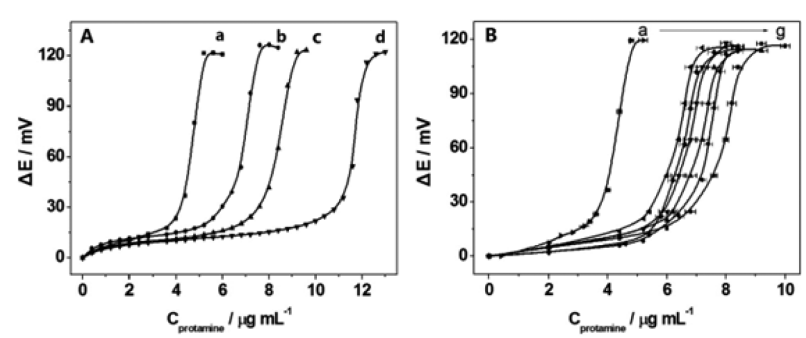

Figure 2. Potentiometric titrations of (A) 0.0 (a), 0.1 (b), 0.2 (c), and $0.4 \mu \mathrm{M}$ LM aptamer (d) and of (B) TBS buffer alone (a) and $0.33 \mu \mathrm{M}$ aptamer incubated at room temperature for $30 \mathrm{~min}$ with 300 (b), 100 (c), 60 (d), 30 (e), and $10 \mathrm{CFU} \mathrm{mL}^{-1}$ Listeria monocytogenes (f) and $0.33 \mu \mathrm{M}$ aptamer alone (g) with $1.0 \mathrm{mg} \mathrm{mL}^{-1}$ protamine. Potentiometric titrations were carried out in $3.0 \mathrm{~mL}$ of TBS buffer by successive addition of $2.0 \mu \mathrm{L}$ of $1.0 \mathrm{mg} \mathrm{mL}^{-1}$ protamine aqueous solution at a $1 \mathrm{~min}$ interval with a syringe pump. Error bars represent one standard deviation for three measurements. Titration curves were obtained by plotting the change in the EMF response vs the concentration of protamine infused. The end point of the titration was determined as the protamine concentration to achieve half of the maximum EMF response $\left(\mathrm{EMF}_{1 / 2, \max }\right)$.

neutralizes the charge of protamine. Therefore, the potentiometric response curve is shifted to a higher mass concentration in the presence of aptamer compared to that of the blank titration. The mass shift can be attributed to electrostatical interaction between the positively charged guanidinium groups of protamine and the negatively charged phosphate groups of the aptamer. ${ }^{30} \mathrm{~A}$ linear relationship between the mass shift and the aptamer concentration can be obtained $\left(\Delta C_{\text {protamine }}=0.77\right.$ $\left.+15.47 \mathrm{C}_{\text {aptamer, }} r=0.995\right)$. This indicates that protamine is suitable as a probe for potentiometric bacterial detection. The titration curves were utilized to determine quantitatively the stoichiometry for the interaction between the LM aptamer and protamine. The neutralization stoichiometry was determined to be $1.32 \mu \mathrm{g} \pm 0.19$ of protamine per $\mu \mathrm{g}$ of the LM aptamer.

Due to the relatively small size of aptamer, it has great accessibility to bacterial cells. The LM apatmer binds specifically to InlA, leading to the formation of the LMaptamer complex. This dramatically inhibits the electrostatic interactions between protamine and the aptamer probably due to less flexibility of the bound aptamer and the steric hindrance. Therefore, significant mass shifts toward lower concentrations of protamine can be observed with increasing cell concentrations (Figure 2B). Such shifts in titration curves provide a solid basis for direct potentiometric detection of LM in aqueous media. Our previous report has shown that the DNA length affects the electrostatic interactions between DNA and protamine. ${ }^{25}$ For bacterium detection, the optimal aptamer length depends on the discrepancy in potential changes before and after bacterium binding. In recent years, a number of aptamers against either the protein targets or the whole cells of LM is available. ${ }^{23,31,32}$ All these aptamers can also be used for potentiometric aptasensing of LM based on the proposed method.

It should be noted that the interference from LM itself could be observed at concentrations higher than $2000 \mathrm{CFU} \mathrm{\textrm {mL } ^ { - 1 }}$ (Figure S2, Supporting Information). Indeed, the zeta potentials for Listeria monocytogenes and other bacteria including Escherichia coli O157:H7, Salmonella typhimurium, and Listeria iuanuii were measured as $-14.2,-14.3,-6.8$, and $-6.7 \mathrm{mV}$, respectively. Therefore, cationic protamine can interact with the negatively charged cell membranes of these bacteria. However, due to the weak bindings between protamine and bacteria, these bacteria may interfere with the potentiometric detection at rather high concentrations.

In this work, zero-current potentiometric measurements were carried out for rapid and sensitive detection of bacterial cells with protamine as an indicator. The amount of protamine infused to the solution was first investigated. As shown in Figure 3A, with extraction of protamine into the organic membrane phase of the electrode via formation of cooperative ion pairs with DNNS, the potentiometric response of protamine reaches a nonequilibrium steady state. ${ }^{29}$ The present polycation-selective electrode shows the sigmoidal relationship between the potential measured and the protamine concentration. When the concentration of protamine added in the solution is more than $10 \mu \mathrm{g} \mathrm{mL}^{-1}$, an equilibrium response can be obtained. Thus, $10 \mu \mathrm{g} \mathrm{mL}^{-1}$ protamine was used for further study.

Since the aptamer/protamine mass ratio plays an important role in the potentiometric detection of LM, the concentration of the aptamer added in the solution was then optimized. The measured potential decreases with an increase of the aptamer concentration due to the electrostatic interactions between protamine and the aptamer. No significant potential response could be observed when $0.33 \mu \mathrm{M}$ aptamer was used (Figure 3B). Therefore, a mass ratio of 1:2.05 (aptamer/protamine) was obtained and employed for measurement of LM (see the Supporting Information).

As shown in Figure 3C, the potential change of the electrode increases as the amount of LM is increased. The potentiometric aptasensing assay is able to detect the target bacterium at

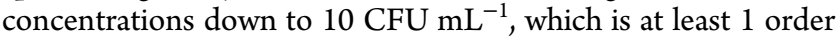
of magnitude lower than those obtained by the immunosensors. ${ }^{8,33}$ The linear dynamic range is between 10 and $500 \mathrm{CFU}$ $\mathrm{mL}^{-1}$ with a linear correlation $r=0.990$ (Figure 3D). A comparison of the present label-free and immobilization-free potentiometric aptasensor and other detection methods is listed in Table 1. Recently, researchers have developed a detection strategy for living bacteria at ultralow concentrations using a carbon nanotube-based potentiometric aptasensor. ${ }^{19,20}$ That method is simple, sensitive, and rapid but may suffer from problems of relatively small potential responses.

To validate the mechanism of the potentiometric assay, we performed control experiments by incubating the LM cells with 

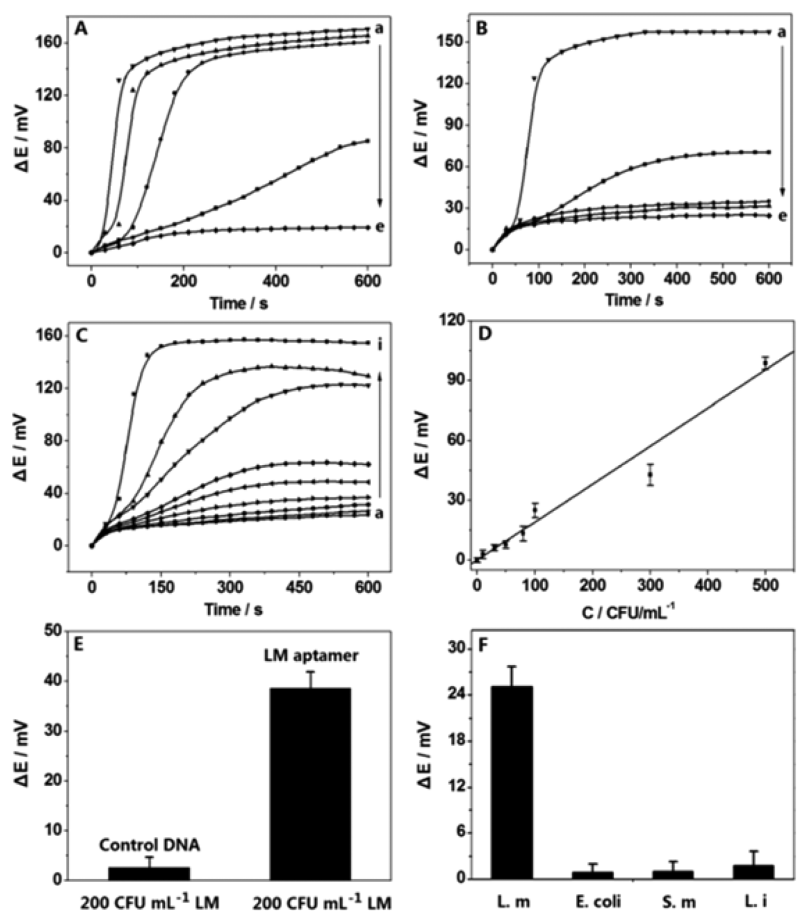

Figure 3. Potentiometric responses of the polycation-sensitive membrane electrode in $3.0 \mathrm{~mL}$ of TBS buffer with (A) protamine of 13.3 (a), 10 (b), 6.7 (c), 3.3 (d), and $0 \mu \mathrm{g} \mathrm{mL}^{-1}$ (e), (B) $10 \mu \mathrm{g} \mathrm{mL}^{-1}$ protamine in the presence of $0(\mathrm{a}), 0.16(\mathrm{~b}), 0.33(\mathrm{c}), 0.66(\mathrm{~d})$, and 1 $\mu \mathrm{M}$ aptamer (e), and (C) $10 \mu \mathrm{g} \mathrm{mL}{ }^{-1}$ protamine in the presence of 0 (a), 10 (b), 60 (c), 80 (d), 100 (e), 300 (f), 600 (g), and 1000 CFU $\mathrm{mL}^{-1}$ Listeria monocytogenes $(\mathrm{h})$ incubated with $0.33 \mu \mathrm{M}$ aptamer and of the TBS buffer alone (i). (D) Plot showing the potential changes over the concentration range of $10-500 \mathrm{CFU} \mathrm{mL} \mathrm{m}^{-1} \mathrm{LM}$. (E) The potential changes in the presence of $200 \mathrm{CFU} \mathrm{mL} \mathrm{mL}^{-1} \mathrm{LM}$ incubated with the control DNA and the LM aptamer. (F) Potential responses to Listeria monocytogenes, Escherichia coli O157:H7, Salmonella typhimurium, and Listeria iuanuii. The concentration of Listeria monocytogenes and that of other bacteria were 100 and $1000 \mathrm{CFU} \mathrm{mL}^{-1}$, respectively. Error bars represent one standard deviation for three measurements.

Table 1. Comparison of the Analysis Times and Detection Limits for Measuring Listeria monocytogenes Using Different Methods

\begin{tabular}{|c|c|c|c|}
\hline method & $\begin{array}{l}\text { analysis time } \\
\text { (h) }\end{array}$ & $\begin{array}{l}\text { detection limit } \\
\left(\mathrm{CFU} \mathrm{mL}^{-1}\right)\end{array}$ & reference \\
\hline dot blot analysis & $>12$ & $2.2 \times 10^{5}$ & 8 \\
\hline $\begin{array}{l}\text { impedemetric } \\
\text { immunosensor }\end{array}$ & 1 & $10^{2}$ & 8 \\
\hline $\begin{array}{l}\text { chemiluminescent } \\
\text { immunoassay }\end{array}$ & $>1$ & $10^{4}$ & 9 \\
\hline $\begin{array}{l}\text { immunosensor based on } \\
\text { SPR }\end{array}$ & $>2$ & $2 \times 10^{6}$ & 33 \\
\hline fluorescent PCR & & 570 & 34 \\
\hline $\begin{array}{l}\text { paper-based microspot } \\
\text { assay }\end{array}$ & 12 & $10^{a}$ & 35 \\
\hline potentiometric aptasensor & 0.67 & 10 & $\begin{array}{l}\text { this } \\
\text { work }\end{array}$ \\
\hline
\end{tabular}

${ }^{a_{T}}$ The concentration unit is $\mathrm{CPU} / \mathrm{cm}^{2}$.

a scramble DNA sequence. As illustrated in Figure 3E, there is no significant potential change for the control DNA, which confirms that the measured potential changes are caused exclusively by the specific interaction between the LM cells and the aptamer. Such interaction is dependent on the unique secondary structure of the aptamer, which benefits the target recognition. ${ }^{36}$ To demonstrate the specificity, the proposed aptasensor was challenged with nontarget foodborne pathogens such as Escherichia coli O157:H7, Salmonella typhimurium, and Listeria iuanuii. As shown in Figure 3F, the responses to other bacteria using the LM aptamer as the sensing element are rather negligible as compared to that to the specific target LM cells even at lower concentrations, thus demonstrating a high degree of specificity. The excellent selectivity may be attributed to the aptamers' ability to bind only to the specific singular protein on the surface of the bacterial cells (i.e., InlA). Taken together, these results clearly demonstrate the essential role of the aptamer in developing the highly sensitive and selective potentiometric sensing strategy.

Some negatively charged species in real samples may electrostatically interact with protamine. These anionic interfering agents may include humic acids, anionic surfactants, and negatively charged bimolecules or organisms. The presence of these interfering agents affects the performance or restricts the applications of the proposed potentiometric aptasensing. In this work, an online filtration system that facilitates separation and preconcentration of the target organism for subsequent detection was developed. Since the LM cells are large biological species, with typical dimensions of $0.4-4 \mu \mathrm{m}$, they can be excluded from the pores $(0.2 \mu \mathrm{m})$. The online filtration was performed via several consecutive steps as shown in Figure S1, Supporting Information, which include filtration of the matrix and washing and elution of the retained cells with the TBS buffer. The outcoming solution of eluted bacteria in TBS was used for potentiometric detection. The system can effectively eliminate the interferences presented in complex sample matrices such as numerous organic or inorganic species. ${ }^{20} \mathrm{~A}$ spike recovery test based on the standard plate count method indicates that an average recovery of ca. $85( \pm 5) \%$ was achieved using $3.0 \mathrm{~mL}$ of TBS as elution buffer. It should be noted that other organisms with negative charges could not be eliminated by the filtration process. However, these bacteria may interfere with the potentiometric detection at rather high concentrations as discussed above.

The water samples collected from coastal areas were analyzed using the present method. However, the LM levels were found to be below the detection limit of the electrode, which is not unexpected because the sample sites are not near the major sources of LM pollutants (Table 2). To evaluate the feasibility of the proposed method, seawater samples were analyzed with the direct potentiometric method by spiking the real samples with the LM suspensions. The values of LM in spiked coastal seawaters obtained by the present electrode were in good agreement with those found by the standard plate count method (Table 2). These results indicate that the proposed

Table 2. Results of the Determination of Listeria monocytogenes in Spiked Coastal Seawater Samples $(n=3)$

$\begin{array}{ccccc}\text { sample } & \begin{array}{c}\text { added } \\ \left(\mathrm{CFU} \mathrm{mL}^{-1}\right)\end{array} & \begin{array}{c}\text { found } \\ \left(\mathrm{CFU} \mathrm{mL}^{-1}\right)^{a}\end{array} & \begin{array}{c}\text { recovery } \\ (\%)\end{array} & \begin{array}{c}\text { results by } \\ \mathrm{SPC}^{a, b}\end{array} \\ \text { seawater 1 } & 0 & 0 & & 0 \\ \text { seawater 2 } & 50 & 44 \pm 3 & 88 & 43 \pm 3 \\ \text { seawater 3 } & 100 & 89 \pm 4 & 89 & 90 \pm 3 \\ \text { seawater 4 } & 200 & 190 \pm 6 & 95 & 179 \pm 5\end{array}$

${ }^{a}$ Average value of three determinations \pm standard deviation. ${ }^{b}$ SPC stands for the standard plate count method using the Listera chromogenic medium. 
method could effectively identify LM in coastal seawater with a simple sample pretreatment.

\section{CONCLUSIONS}

In conclusion, the potentiometric aptasensor based on the polycation-sensitive electrode outperforms the present immunoassay methods and is highly suitable for sensitive and selective detection of LM in an aquatic environment. The effective potentiometric transduction with the polycationsensitive membrane electrode suggests that this technique could be operated in turbid media. Owing to the generic and modular nature of the aptamer, we envision that this methodology will be widely applicable to the development of label-free aptasensors for rapid determination of a wide range of other bacteria species where specific binding aptamers can be selected.

\section{ASSOCIATED CONTENT}

\section{S Supporting Information}

Additional information as noted in text. This material is available free of charge via the Internet at http://pubs.acs.org.

\section{AUTHOR INFORMATION}

\section{Corresponding Author}

*Telephone: +86 535 2109156. Fax: +86 535 2109000. E-mail: wqin@yic.ac.cn.

\section{Notes}

The authors declare no competing financial interest.

\section{ACKNOWLEDGMENTS}

This work was financially supported by the National Natural Science Foundation of China $(41176081,21207156)$ and the Science and Technology Project of Yantai (2012132).

\section{REFERENCES}

(1) Boehm, A. B.; Yamahara, K. M.; Love, D. C.; Peterson, B. M.; Mcneill, K.; Nelson, K. Environ. Sci. Technol. 2009, 43, 8046-8052.

(2) Ramaswamy, V.; Cresence, V. M.; Rejitha, J. S.; Lekshmi, M. U.; Dharsana, K. S.; Prasad, S. P.; Vijila, H. M. J. Microbiol. Immunol. Infect. 2007, 40, 4-13.

(3) Center for Disease Control and Prevention. http://www.cdc. gov/listeria/outbreaks/cheese-09-12/index.html. Accessed March 30, 2013.

(4) Lu, X. N.; Rasco, B. A.; Kang, D. H.; Jabal, J. M. F.; Eric Aston, D.; Konkel, M. E. Anal. Chem. 2011, 83, 4137-4146.

(5) Elshenawy, M. A. Epidemiol. Infect. 2006, 134, 752-757.

(6) Hamon, M.; Bierne, H.; Cossart, P. Nat. Rev. Microbiol. 2006, 4, 423-434.

(7) Chen, G. X.; Walker, S. L. Environ. Sci. Technol. 2012, 46, 87828790 .

(8) Wang, R. H.; Ruan, C. M.; Kanayeva, D.; Lassiter, K.; Li, Y. B. Nano Lett. 2008, 8, 2625-2631.

(9) Magliulo, M.; Simoni, P.; Guardigli, M.; Michelini, E.; Luciani, M.; Lelli, R.; Roda, A. J. Agric. Food Chem. 2007, 55, 4933-4939.

(10) Jyoti, A.; Vajpayee, P.; Singh, G.; Bali Patel, C.; Chand Gupta, K.; Shanker, R. Environ. Sci. Technol. 2011, 45, 8996-9002.

(11) EI Marrakchi, A.; Boum'handi, N.; Hamama, A. Lett. Appl. Microbiol. 2005, 40, 87-91.

(12) Mannoora, M. S.; Zhang, S. Y.; Link, A. J.; McAlpine, M. C. Proc. Natl. Acad. Sci. U.S.A. 2010, 107, 19207-19212.

(13) Iliuk, A. B.; Hu, L. H.; Andy Tao, W. Anal. Chem. 2011, 83, $4440-4452$.

(14) Yildirim, N.; Long, F.; Gao, C.; He, M.; Shi, H. C.; Gu, A. Z. Environ. Sci. Technol. 2012, 46, 3288-3294.

(15) Mayer, G. Angew. Chem., Int. Ed. 2007, 48, 2672-2689.
(16) Wang, Y. X.; Ye, Z. Z.; Si, C. Y.; Ying, Y. B. Chin. J. Anal. Chem. 2012, 40, 634-642.

(17) Hamula, C. L. A.; Zhang, H. Q.; Li, F.; Wang, Z. X.; Le, X. C.; Li, X. F. TrAC, Trends Anal. Chem. 2011, 30, 1587-1597.

(18) Paniel, N.; Baudart, J.; Hayat, A.; Barthelmebs, L. Methods 2013, 64, 229-240.

(19) Zelada-Guillén, G. A.; Riu, J.; Düzgün, A.; Rius, F. X. Angew. Chem., Int. Ed. 2009, 48, 7334-7337.

(20) Zelada-Guillén, G. A.; Bhosale, S. V.; Riu, J.; Rius, F. X. Anal. Chem. 2010, 82, 9254-9260.

(21) Labib, M.; Zamay, A. S.; Kolovskaya, O. S.; Reshetneva, I. T.; Zamay, G. S.; Kibbee, R. J.; Sattar, S. A.; Zamay, T. N.; Berezovski, M. V. Anal. Chem. 2012, 82, 8114-8117.

(22) Ding, J. W.; Chen, Y.; Wang, X. W.; Qin, W. Anal. Chem. 2012, 84, 2055-2061.

(23) Ohk, S. H.; Koo, O. K.; Sen, T.; Yamamoto, C. M.; Bhunia, A. K. J. Appl. Microbiol. 2010, 109, 808-817.

(24) Shvarev, A.; Bakker, E. Anal. Chem. 2005, 77, 5221-5228.

(25) Ding, J. W.; Qin, W. Biosen. Bioelectron. 2013, 47, 559-565.

(26) Qin, W.; Liang, R. N.; Fu, X. L.; Wang, Q. W.; Yin, T. J.; Song, W. J. Anal. Chem. 2012, 84, 10509-10513.

(27) Ye, Q. S.; Meyerhoff, M. E. Anal. Chem. 2001, 73, 332-336.

(28) Briandet, R.; Meylheuc, T.; Maher, C.; Bellon-Fontaine, M. N. Appl. Environ. Microbiol. 1999, 65, 5328-5333.

(29) Fu, B.; Bakker, E.; Yun, J. H.; Yang, V. C.; Meyerhoff, M. E. Anal. Chem. 1994, 66, 2250-2259.

(30) Prieto, M. C.; Maki, A. H.; Balhorn, R. Biochemistry 1997, 36, 11944-11951.

(31) Duan, N.; Ding, X. Y.; He, L. X.; Wu, S. J.; Wei, Y. X.; Wang, Z. P. Food Control 2013, 33, 239-243.

(32) Liu, G. Q.; Lian, Y. Q.; Gao, C.; Yu, X. F.; Zhu, M.; Zhong, K.; Chen, X. J.; Yan, Y. J. Integr. Agric. 2014, 13, 1121-1129.

(33) Wang, Y.; Knoll, W.; Dostalek, J. Anal. Chem. 2012, 84, 83458350.

(34) Alarcón, B.; García-Cañais, V.; Cifuentes, A.; González, R.; Aznar, R. J. Agric. Food Chem. 2004, 52, 7180-7186.

(35) Jokerst, J. C.; Adkins, J. A.; Bisha, B.; Mentele, M. M.; Goodridge, L. D.; Henry, C. S. Anal. Chem. 2012, 84, 2900-2908.

(36) Ellington, A. D.; Szostak, J. W. Nature 1990, 346, 818-822. 